\title{
膜構造建築物用膜材料の屋外ばくろによる \\ 耐久性能評価に関する研究 \\ PERFORMANCE EVALUATION ON MEMBRANE MATERIALS FOR MEMBRANE STRUCTURE UNDER OUTDOOR EXPOSURE TESTS
}

\author{
榆木 堯* \\ Takashi NIREKI
}

\begin{abstract}
Performance overtime of membrane materials for membrane structure has prominent important role as a front line of defence barrier between inner and outer space of the structure. This paper deals with the results of ten years out door exposure tests for PVC coated polyester fabrics, intended to obtain much practical and applicable performance data for design for durability or service life prediction of membrane structure. It could be conducted that behaviour of degradation in time, especially, tensile and tear strength are comparatively critical in view of structural safety aspect and this could be applicable as performance based test data for setting service life of the membrane structures and also setting some measures for maintenance operation .
\end{abstract}

\author{
Keywords: Performance over time, Durability, Membrane material, Membrane structure, Outdoor exposure \\ test, Service life prediction \\ 耐久性能、耐久性、瞙材料、膜構造物、屋外ばくろ試験、耐用性予測
}

\section{1.はじめに}

近年、建築の諸活動は建築に要求される性能を基盤として検討す る指向が重視され、建築法規の大系にも導入されるようになって来

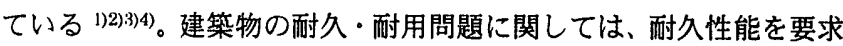
性能の一つとして把えて建築物の設計・施工・保全活動の中で活用 する指向がある5)(7)8)。この指向を具現化するためには耐久・耐用性 を重視した性能設計が必要となり、この設計が行えるためには建物 全体とそれを構成する部位から建築材料の耐久性能に係わる性能テ 一タ・情報が蓄積されていることが不可欠になる。

膜構造建築物における膜材料の果たす役割は、通例ではこの材料 が内外空間を隔てる唯一のバリヤーであることもあって、建築物全 体の機能・性能を左右するほどに重要である。一方で膜構造建築の 歴史は浅く、当該建築物の耐用性を検討する基本になる膜材料自体 の耐久性能に関する性能データの蓄積も未だ少ない。

膜構造建築は、その構造形式により骨組膜構造物、サスペンショ ン膜構造物及び空気膜構造物に大別されている ${ }^{9)}$ 。これらに使用さ れる代表的な膜材料はカラス、ポリアミド、ポリエステル等の絨維 織物を基布として、これにフッ素樹脂や塩化ビニル系樹脂、クロロ プレン系ゴム等がコーティングされ、これ等は構造形式と建物用途 に応じて使い分けられている。
本研究は、ポリエステル繊維織物を基布とし塩化ビニル樹脂がコ 一ティングされた膜材料を対象とし、10 年間に亘る各種の屋外ばく ろ試験を実施し耐久性能に関わる諸性能デー夕を得ることと、得ら れたデータを耐久性能を重視した性能設計の基礎資料として活用す ることを主目的としている。なお、本稿で使用している耐久・耐用 関連用語の意味は次の通りである。

耐久性：建築物またはその部分の劣化に対する抵抗性

耐久性能: 建築物またはその部分の性能をある水準以上の 状態で維持する能力

耐久設計：建築物またはその部分の性能をある水準以上の 状態で継続して維持させるための設計

耐用性：建築物またはその部分が機能を持続して維持す る能力

耐用年数: 建築物またはその部分が使用に耐えなくなるま での年数

2. 耐久性能を重視した設計における酎久性能データの必要性

\section{1 一轧建筑物についての検时}

多くの建築物はその耐久性を考慮に入れているとしても、 


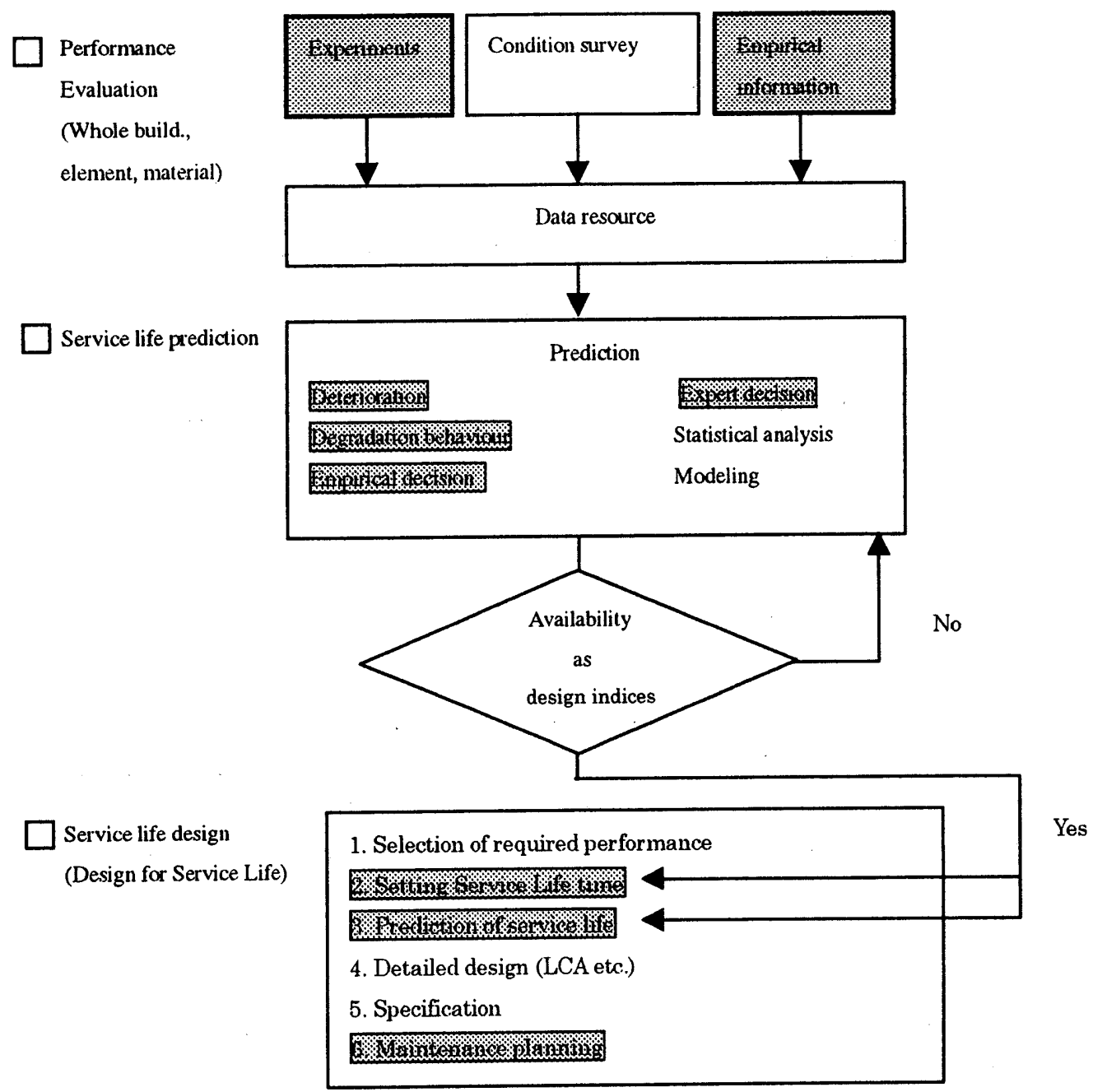

Fig.1 Role of performance evaluation and service life prediction for supporting service life design

耐久性能を重要視して計画されているものは少なく、建築物が完成 したあとの保全までを考虑にいれた性能指向による計画・設計の方 法が確立される必要がある。文献 5) は、この方法論の確立のため の道筋を示したものともみられるが、その取䋔めまでに 10 余年を 要し、その間に同類の指向を目途とした建築省総合技術開発プロジ エクト ${ }^{6)}$ の成果も採り入れられている。文献 7 ）は新規作成になる ISO の規格で、その基本は文献 5）及び6）と軌を一にし、とくに 文献 5）の英文版 ${ }^{10)}$ を踏襲している部分が多い。これらの内容は Fig.1 最下段のように略記できる。しかし、この部分を具体的に実行するため には如何にして建築物全体の目標耐用年数を設定するか、さらにそれに 見合って構成部位・部材・材料のもっている耐用年数を推定するかが重 要である。このため Fig.1 の中段に示す耐用性能予測とその技術が必要 となり、さらに Fig.1 の最上段に示した耐久性・耐久性能に関する実験・ 検証・実態調査結果やエキスパートの知見を含む性能テーータの蓄積が不 可欠となる。

\section{2 膜様造建築物についての検討}

我国の現行法規のもとで、膜構造建築物には「建築基準法第 38 条 (特殊の材料又は構法)」が適用されている。膜構造建筑物の建設 に関する要素技術は、比較的近年に開発されたものが多い。従って、
古い歴史をもっている他の構造形式による建築物と比較すると、 その設計・施工・保全には性能指向が導入されている。

用途・規模・主要構造部に制限（例えば、骨組膜構造、支点間距 離 $4 \mathrm{~m}$ 以下、合計面積 $3000 \mathrm{~m}^{2}$ 以下の展示場）があるものは、「特 定膜構造建策物」（建設省東住指発第 362 号、昭和 62 年）として取

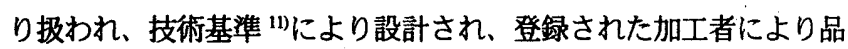
質管理要領 ${ }^{11)}$ で膜材料が取り扱われている。さらに建設後は保全計 画指針 ${ }^{12}$ に基づいて、建設後 1 年目、それ以降は 3 年毎に定期点検 が実施されることになっている。従って、この特定膜構造建築物で は、設計時にあらかじめこの保全条件を組み込んでおくことが可能であ る (Fig.1 最下段参照)。

耐久性能が未知なもの、確たる検証が得られていないものの耐用性を 評価する際には、その使用期間中での維持保全条件を加味して行うこと が合理的である。現在使用されている膜材料の範囲だけでも多種に亘り、 今後とも新しい素材や改良された技術による材料の出現も予想される。 本研究は昭和 58 年度に開始されており、その目的範囲は Fig. 1 中で 網掛けされた部分であるが、得られた結果が現行の諸基準の充実や裹付

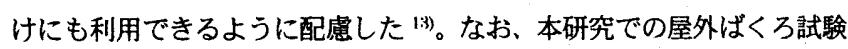
開始後 7 年目 ${ }^{14}$ 及び 10 年目 ${ }^{15)}$ の結果の一部はすでに報告されている。 


\section{3. 㩆験対象と試験体}

本研究では、試験対象はポリエステル織維織物を基布として表面 に塩化ビニル樹脂. (PVC と略称) をコーティングした膜材料に限定 し、異なる代表的な製造業者 3 社の製造になる市販品を選定してい る。Table.1にその詳細を、また、Fig. 2 に構成の模式図を示す。因 みにこの種類の膜材料は大規模な恒久膜構造建築物で主として用い られているガラス繊維織物と四ふっ化エチレン系樹脂を組み合わせ たものと比較すると機械的強度も低く、耐用性も劣るとされている が、使用実績が長く、性能／価格比の面が評価され、多用されてい る材料である。

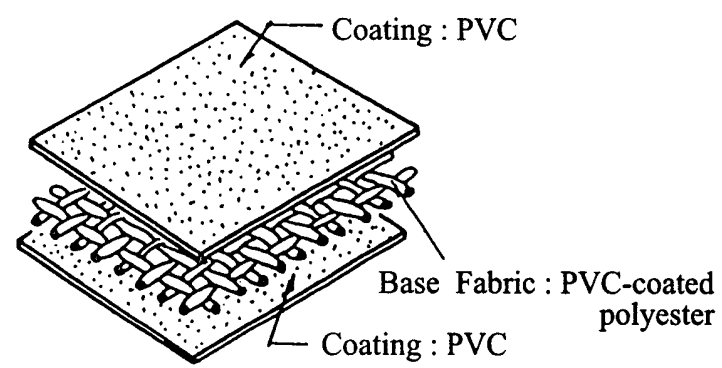

Fig.2. Composition of PVC-coated polyester plain-weave fabric

\section{4. 屋外ばくろ咭铪}

\section{1 屋外ばくろ試䤅場所及び期間}

茨城県つくば市立原 1 , 建設省建築研究所 屋外ばくろ試験場 (北 緯 $36^{\circ} 7^{\prime} 38^{\prime \prime}$, 東経 $140^{\circ} 4^{\prime} 39^{\prime \prime}$ ，海抜 $29 \mathrm{~m}$ ）である。但し、4.2(2) 実大レベルの試験については同ばくろ試験場西側構内とした。試験 期間は 1982 年 11 月より 1991 年 11 月の 10 年間である。

\section{2 屋外ばくろ式験方法}

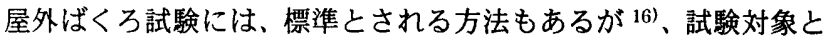
当該試験で得ようとする結果によって方法の詳細は異なり、特に耐
Table 1 Properties of PVC-coated plain-weave fabric (warp $\times$ fill)

\begin{tabular}{llllllll}
\hline $\begin{array}{l}\text { Speci- Yarn Density } \\
\text { men }\end{array}$ & $\begin{array}{l}\text { Composition of the } \\
\text { PVC compound } \\
\text { (unit:parts by weight) }\end{array}$ & \multicolumn{2}{c}{ Thick- Weight } \\
ness
\end{tabular}

久性能データを得ようとする場合には単に耐久性デー夕を期待する

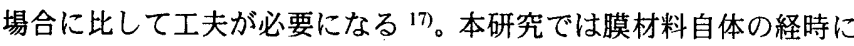
よる劣化特性を究明することと、Fig.1 中最下段にある耐用年数の 予測、耐用年数の設定、さらに、維持保全計画の内容に関係する基 礎データを得ることを意図して、Fig. 3 及び Fig.4にその概要を示す ような各種の方法を採用した。

（1）材料レベルの試験 膜材料は全て製品の定尺幅 $(900 \mathrm{~mm})$ で ばくろされ、評価の際にこれより必要数（破壊を伴う評価では、 イニシャルはたて系、横糸方向とも $\mathrm{n}: 20$, その他は $\mathrm{n}: 5$ 個） をカットし、採取した。

i）南面向け $30^{\circ}$ 、南面向け $90^{\circ}$ 、北面向け $90^{\circ}$ いずれも無 加力である。これらは通常の外装材料等で耐久性評価のために 多用されている方法と同様で、他の建築材料との耐久性の比較 も意図している。(Photo.1 及び 2 参照。)

ii）南面向け $30^{\circ}$ 、北面向け $30^{\circ}$ 、南面向け $90^{\circ}$ 、北面向け $90^{\circ}$ いずれも緊張加力してあり、膜材料へ使用時の緊張力が作

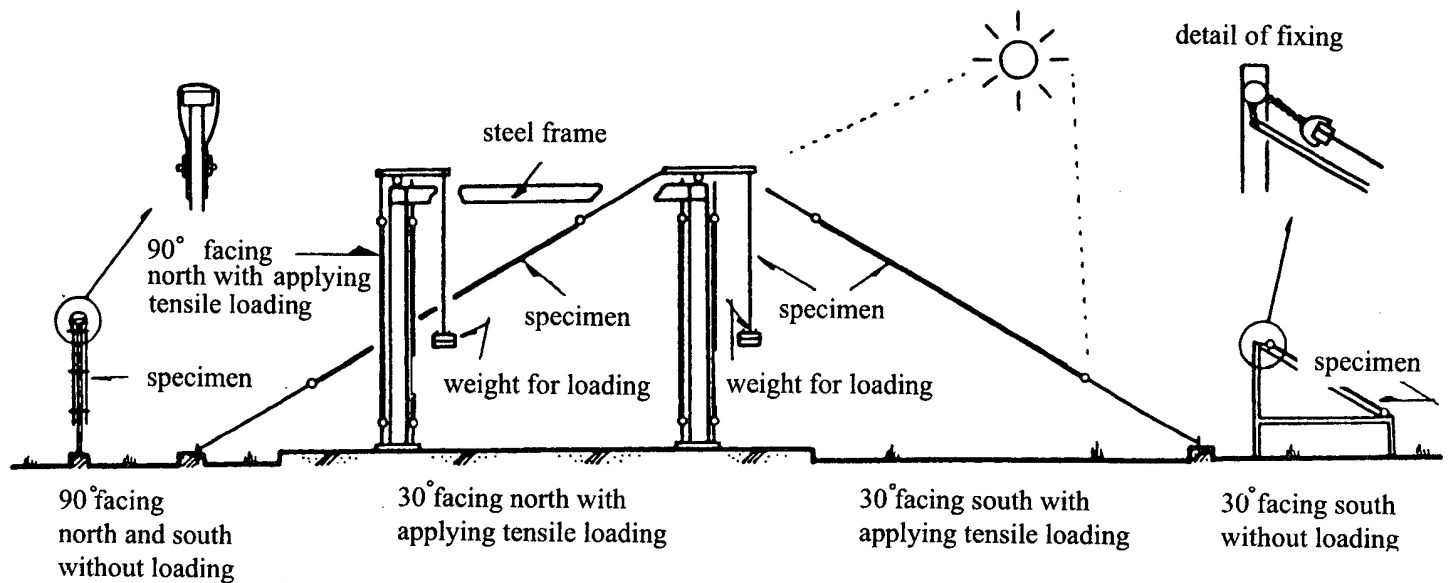

Fig. 3. Outline of outdoor exposure test(AT MATERIAL LEVELL) 
用している状態の再現を意図した (Photo.3 参照)。加力は 専用の鋼製治具と鍾を組み合わせて、イニシャルの引張強 度の $10 \%$ 相当としてある。なお、これらは Table.1 中のA 試験体のみを対象としている。また、南・北面向け $90^{\circ}$ で は、裏面からの劣化の影響を考慮して同種の瞙材料で裏側 全面を覆ってある。

(2) 実大レベルの試験 Fig.4及びPhoto.4に示すように骨組 膜構造形式により、文献 11)の基準に準拠し鋼製ラチスト ラス架構を設け、3 種類の膜材料で張り上げられている。 なお、膜材料相互間は熱溶着により接合した。

試験の対象は、東・西面（妻面）は除いて南面向きの垂 直壁 $\left(90^{\circ}\right)$ 、屋根南面向き $\left(20^{\circ}\right)$ 、屋根北面向き $\left(20^{\circ}\right)$ 、及び北 面向きの垂直壁 $\left(90^{\circ}\right)$ である。評価の際は、これら 4 つの部 位から所要の面積分がカット・採取される。採取された部 分は空白になるが、その時点で劣化診断を行い、的確な補 修方法によって同種の膜材料で補修する。この補修された 部分はさらに経時後に補修箇所（接合部分）を中央とした 試料を作成して引張り試験を実施し、補修効果の評価を行 うこととしている。

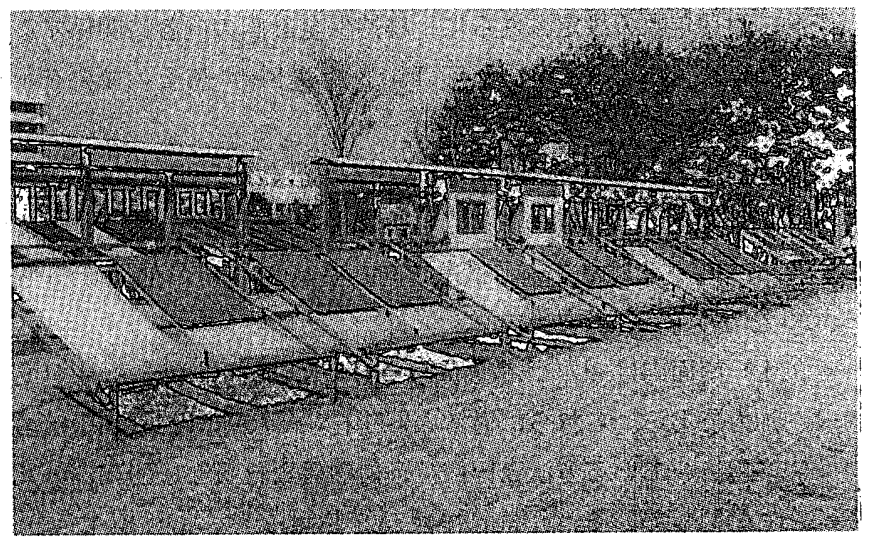

Photo.1 Outdoor exposure $-30^{\circ}$ facing south, At material level.

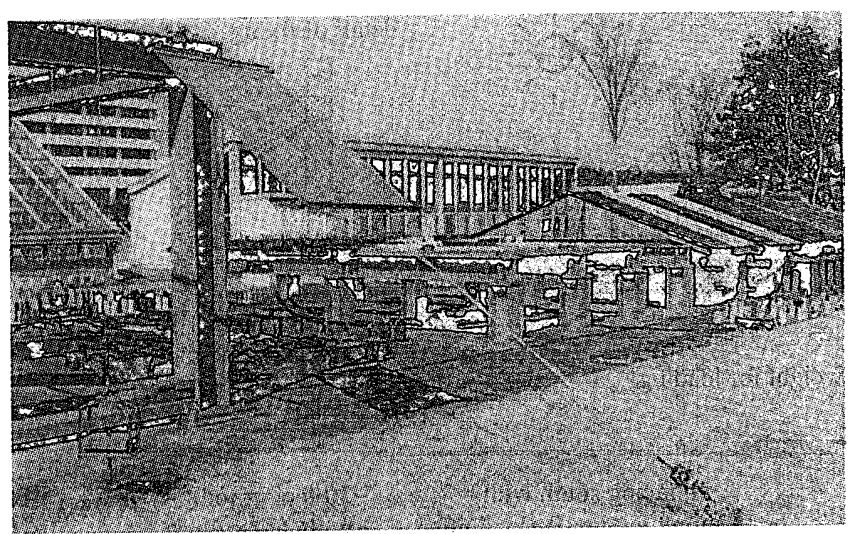

Photo. 3 Outdoor exposure $-30^{\circ}$ facing south, under loading, At material level.

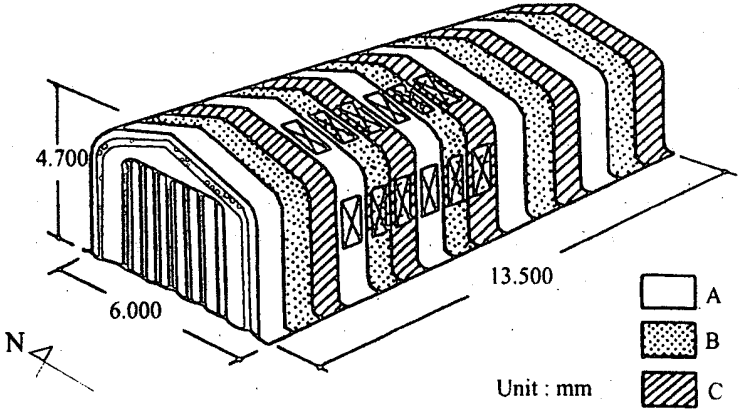

Fig.4 Outline of outdoor exposure test (at full-scale level)

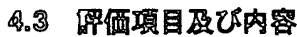

経時後の評価項目とその内容の概要を Table. 2 に示す。評価は目 視観察によっても実施し、膜材料の污れ、かびの発生、光沢、白亞化、 ひびわれ・ふくれ（コーティング材と基布との間に生じるもの）・は がれ（コーティング材と基布との間に生じるもの）と、実大レベル における膜材料相互の接合部分のはがれ、水漏れを観祭している。 さらに上記の他に走査型電子顕微鏡による膜材料の組織構造の変化、 蛍光X線分析、膜材料中の樹脂分の質量変化の分析も実施した。

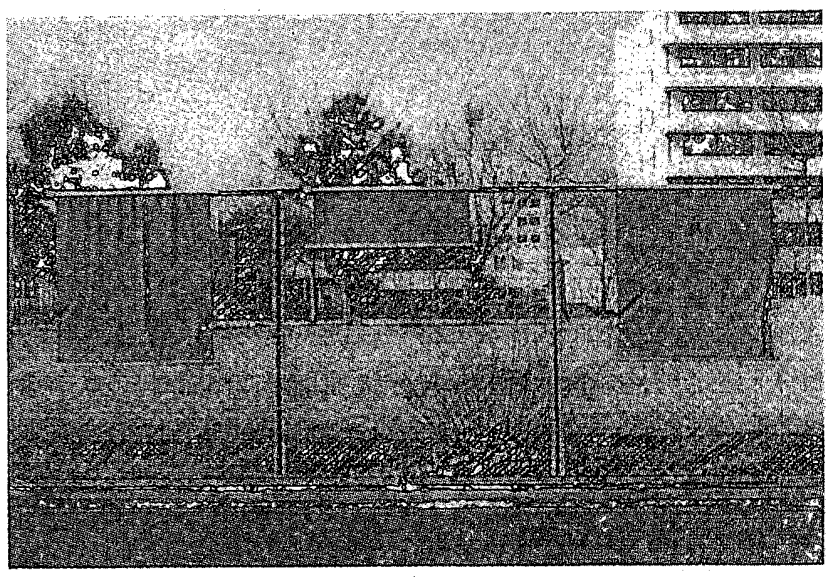

Photo. 2 Outdoor exposure $-90^{\circ}$ facing south, At material level

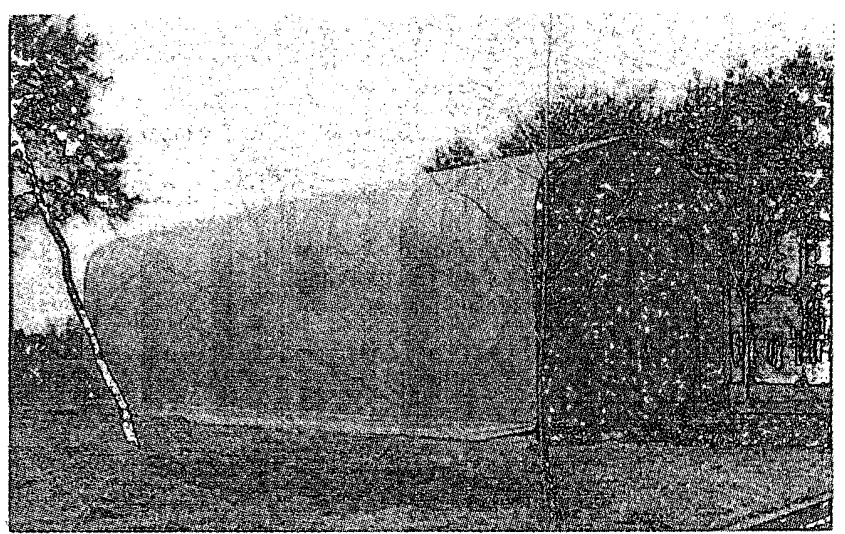

Photo.4 Outdoor exposure -view form south, At full-scale level 


\begin{tabular}{llrc}
\hline Items & Test method and condition & Size of specimen \\
\hline Mass & JIS K 6328 & & $10 \mathrm{~cm} \times 10 \mathrm{~cm}$ \\
Weight & JIS K 6328 & Tension speed: $20 \mathrm{~cm} / \mathrm{min}$ & $10 \mathrm{~cm} \times 10 \mathrm{~cm}$ \\
Tensile strength & JIS L 1096.6.12.1 strip method & Clamp distance: $20 \mathrm{~cm}$ & $30 \mathrm{~cm}$ \\
Elongation & & Tension speed: $20 \mathrm{~cm} / \mathrm{min}$ & $10 \mathrm{~cm} \times 25 \mathrm{~cm}$ \\
Tear strength & JIS L 1096.6.15.1 Single tongue method & & $2 \mathrm{~cm} \times 15 \mathrm{~cm}$ \\
Stiffness & JIS L 1096.6.19.2 Slide method & & $15 \mathrm{~cm} \times 15 \mathrm{~cm}$ \\
Discolouration & JIS Z 8722 & & $30 \mathrm{~cm} \times 20 \mathrm{~cm}$
\end{tabular}

\section{5. 諽䀦桔果と考察}

耐久性能を重視した建築物の設計において、建物全体から部品・ 材料に至る各レベルが耐用に達したと判断する項目として文献 7 ） の原案では以下の 9 項目をあげている。即ち、構造安全性、水密・ 気密性、美観、快適及び衛生、エネルギ一効率、経済性、予見しう る危害への対応性と技術的及び物理的陳腐化である。これらのうち でどれを優先して考えるかは、各建築物へのニーズや要求条件によ ると思われるが、本研究で対象としている膜材料を使用した建築物 の場合、共通的にまず優先的に考慮すべき項目は構造安全性で当該 実験研究の中では引張強度と引裂強度がこれに該当する。そこで以 下にその評価結果を中心に考察を行う。

\section{1 材料レベルでの俩価}

Fig. 5 及び 6 に引張強度及び引裂強度の経時変化について残存率 で求めた結果を示す。基布の繊維方向はたて方向のみとしている。 対象とした 3 種類のうち、1 種類（試験体C）は他の 2 種類に比し て異なる傾向を示し、とくに Fig.5 では明らかに他に比して引張強 度低下が少ない。引張・引裂特性に及ぼすばくろ角度の影響は認め られ、図中には示されていないが、北面向き $90^{\circ}$ にばくろされたも のは各図において他の 2 つの結果の中間に位置している。膜材料に 加力しておいたものについても同様である。加力はイニシャル引張 強度の $10 \%$ 程度の低い加力でも結果に有意に影響を及ぼすと予測 されたが、実際には引張・引裂の両特性については経時変化に顕著 な差は認められない。実際の膜構造建築物においてこの程度の加力 状態下の影響は一般の平坦部位である限り軽微であると解釈される。

Fig.6 にみられるように、南面 30 にば゙くろされたものは 3 年目 にして引裂強度が約 $50 \%$ 以下に、 7 年目で $30 \% 、 10$ 年間経過する と $20 \%$ 程度になる。これを数值だけからみると、外力の作用により 破断し易い状態に至っていることを示している。

引張強度と引裂強度の間の関係は、試験開始後 3 年及び 7 年まで は、両者の相関を検討して来た ${ }^{14)}$ 。その目的は、いずれか一方の評 価で他方を代表させる、または、他方が予想可能であると至便であ ると考えたものであったが、経時変化の傾向と程度について判断し うる結果は得たが、定量的に相関は認められない。

\section{2 実大レベルでの評価}

Fig. 7 及び 8 に引張強度及び引裂強度の経時変化について残存率 で求めた結果を示す。まず、両特性ともに変化の傾向は屋根北面向 きは図中の屋根南面向きより勾配が緩く、南面向きの壁では図中に 示した北面向き壁のそれに比して急な勾配を示している。ここでも 5.1 材料レベルの評価において述べたと同様に、対象とした膜材料

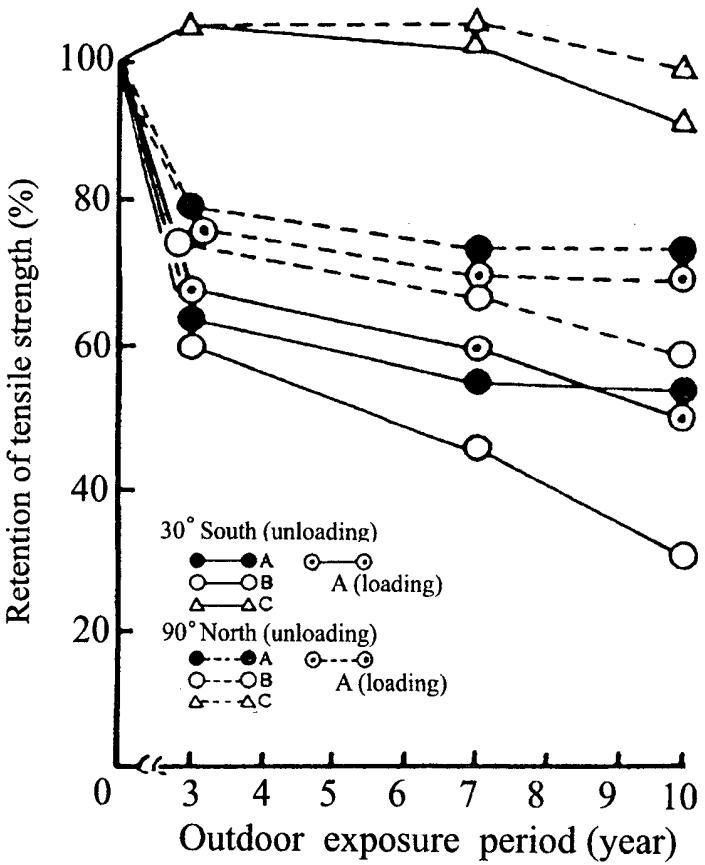

Fig.5. Result of tensile strength retention under various conditions at material level

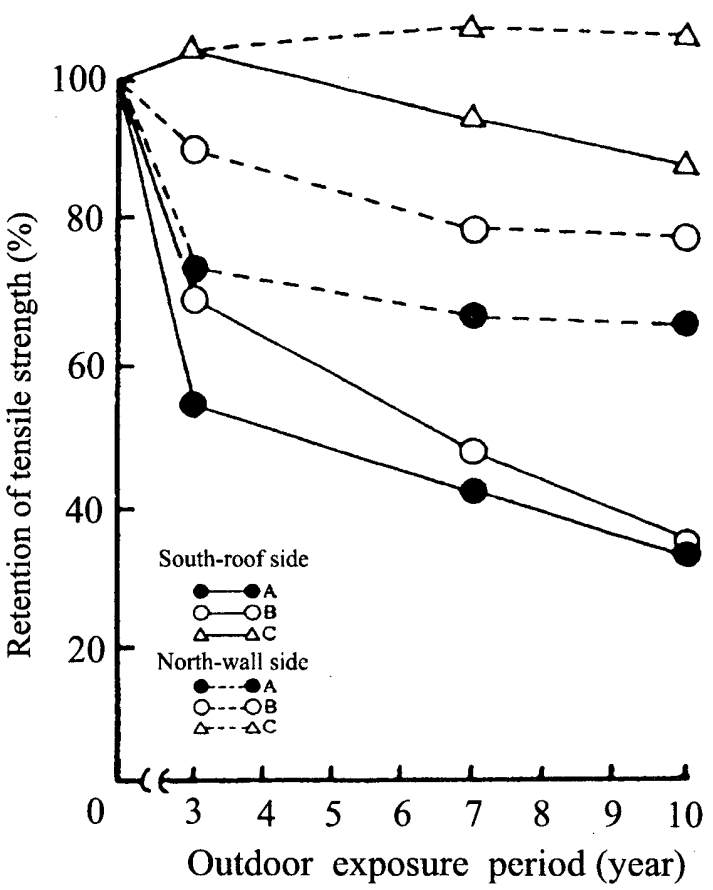

Fig.6. Result of tensile strength retention at full scale level 
のうち、1 種類（試験体 C）だけが他に比して異なる挙動を示して いる。Fig. 5 と7、Fig. 6 と 8 を比較するとそれぞれ類似した傾向が 認められているため、この差は試験体の相違、製品の差であると推 定される。本研究では当時の品質基準に合致し、かつ使用実績のあ る代表的市販製品の中から検討の上選定した 3 種類であるため、設 計時に現実的な膜材料の選定を行うとき、7.まとめに述べるような 留意が必要となることを示している。

引張・引裂の双方ともに、強度低下は、北面向き壁<南面向き壁 <北向き面屋根＜南向き面屋根の順序で大きくなる傾向が認められ る。実大レベル試験体の屋根の勾配は、南面・北面とも約 $20^{\circ}$ であ る。従って、屋根部位でのばくろされている角度は、5.1 に示す材 料レベルでの南面 $30^{\circ}$ 及び北面 $30^{\circ}$ の結果に近く、Fig.5 と 7 の結果 を比較すると両者が近似していることが判る。しかし、後述するよ うにばくろされた試験体を目視観察する限り明らかに表面の劣化は 屋根部位にばくろされたものの方が壁の場合より進行が速いと判断 できる。実大レベルの評価では材料レベルの場合の評価で期待し えない全く異なった結果が得られている。例えば Photo.4に見られ るように東西方向でたて 3 枚毎に污れによる暗色が明瞭に認められ る。この污れは、内部空間に入ってみると極めて明暸に透光性の差 として実感できる。この程度までの污れはすべての条件の材料レベ ル試験では認められない。屋根部位にばくろされたものは、約 7 年 目から表面の樹脂層下の繊維織物の形態が露出判別できる状態にな り、この現象も材料レベルの試験では認められない。但し、引張・ 引裂強度には両レベル間ともに極端な変化は認められない。

膜材料はミシン縫製による接合加工がなされ、妻側の一部にはこ の加工が採用されている。縫製にはナイロン糸が用いられているが ばくろ 7 年間程度で糸が劣化し、次第に針穴を残して堿失してくる。 また同じく妻側に膜材料端部を緊張固定するためのナイロン製ロー プが使用されているが、外部に露出している部分は 7 年目当たりか ら劣化が認められてくる。別に、このロープはハトメと呼ばれる電 気めつき処理された薄板リングをあらかじめ膜材料に取り付けてお き、これを介して緊張力が伝達されるようになっている。

ハトメは7 年目程度で発錆が始まる。膜材料の内部側表面には著 しい結露が発生し、表面に治って結露水が流下する。鋼製トラス・ 横架材自体の表面にも結露は発生するが、とくに膜材料と接する部 分ではこれを予想した防食処理性能が要求される。

前述のミシン糸、ロープ、ハトメ及び鋼製構造部材の劣化は、瞙 構造建築物の維持管理の中でも留意されるべき重要事項である。

維持保全指針 ${ }^{121}$ の中で補修方法は提案されているが、本研究で 対象とした膜材料の場合、膜材料表面の樹脂分が劣化により隇失し た状態（例えば、ばくろ 7 年後の屋根面）に至ると、新規の補修用 膜材料と既存膜材料とを熱溶着で接合することが困難になる。熱溶 着接合は、膜材料を重ね合せてこの部分を加熱溶着させるもので、 膜材料表層の樹脂分が少ないとその効果が期待できなくなる。

なお、本研究では補修効果の検証のため $4 \cdot 2$ (2) に示した実験を 行ったが、補修後 7 年間以内では少なくとも補修部分の引張強度は、 補修部以外のそれを下回っておらず効果が確認できている。

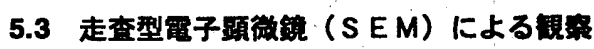

Photo.5〜8 KS E Mにより表面状熊が判断し易いよう低倍率で

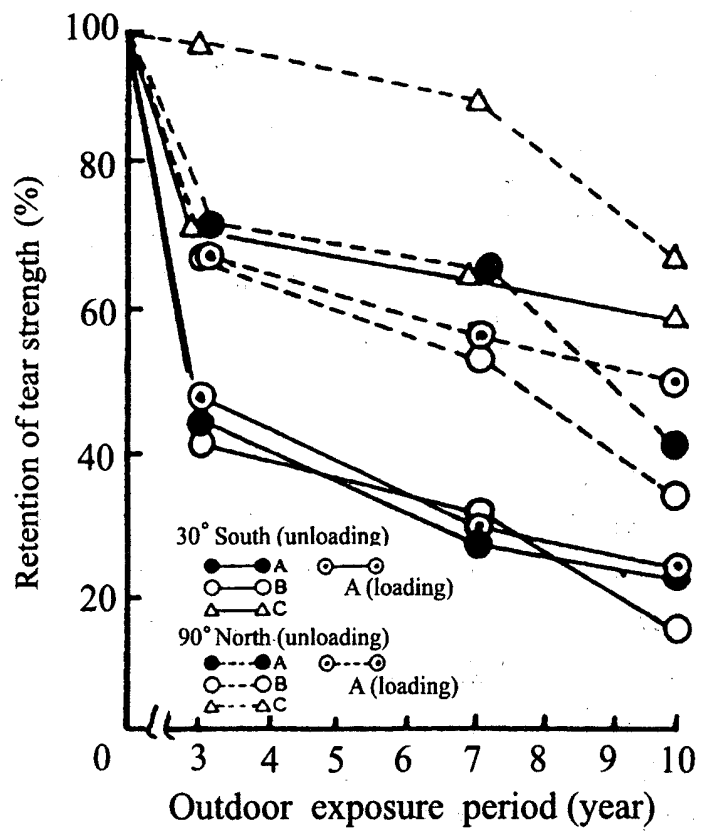

Fig.7. Result of tear strength retention under various conditions at material level

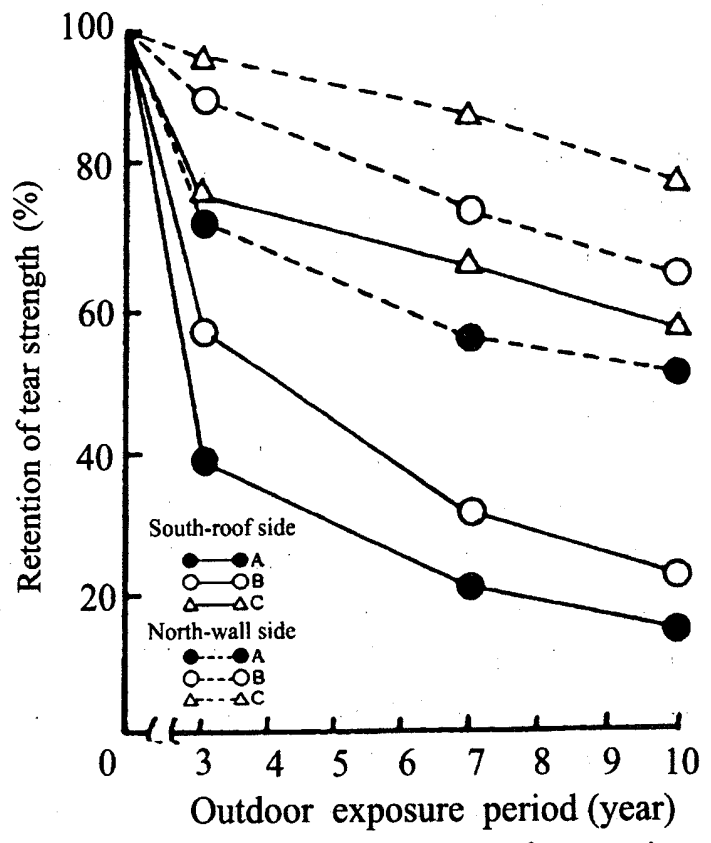

Fig.8. Result of tear strength retention at full-scale level

撮影したものを示す。Photo.5 では $30^{\circ}$ 南面向きの基布の䌦維の一 部が露出しているが、南面向きのばくろ角度が $90^{\circ}$ の場合では Photo.6 の程度となる。Photo.7 は前述のように目視でも基布の存 在が判別でき、これを拡大するとかなり表面の樹脂分が欠落してい ることが判る。一方 Photo.8 では表面に樹脂のひびわれが認められ る程度で基布は露出していない。イニシャルを $100 \%$ とした樹脂分

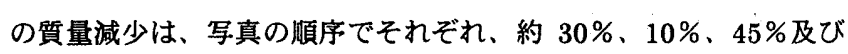
$6 \%$ 程度である。樹脂は基布の雨面で均等にコーティングされてい ると思われ、経時後も膜材料の裹面(非ばくろ面)はとくに異常が観 察されていないことから、減少分は被ばくろ面からのみと考えると、 上記の $45 \%$ 程度の減少は非ばくろ面のコーティング層がほほ失わ れているともいえる。 


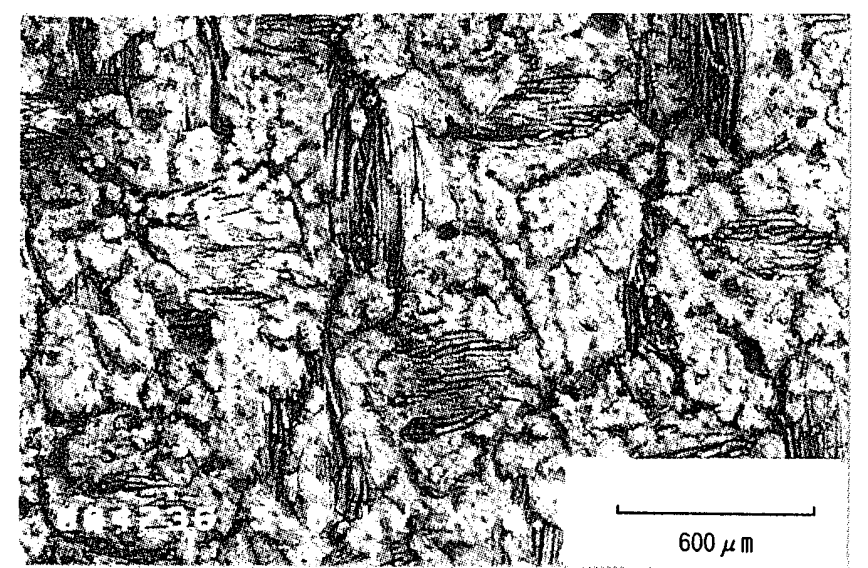

Photo. 5 Behaviour of surface deterioration by SEM after 10 years, $30^{\circ}$ facing south At material level

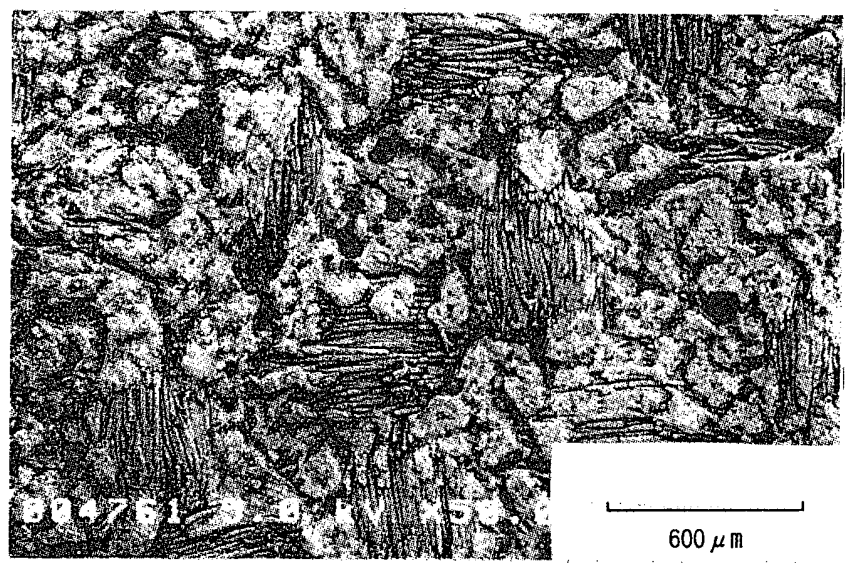

Photo.7 Behaviour of surface deterioration by SEM

after 10 years, roof facing south At full-scale level

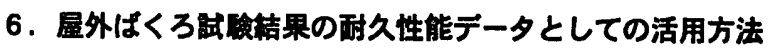

文献 5 ）、6)、及び7）での考え方では、先ず目標之する耐用年 数を設定することから始まり、以降は材料特性、劣化外力、施工状 況、維持保全条件を加味し、設定された慗準耐用年数に合致させる ように組み立てられている。この考え方の実用化には如何にして最 初に目梅耐用年数を設定するかが要点になるが、この部分に対する 十分な検討は現状なされていない。目標耐用年数を設定する当事者 は多くの場合設計者であり、そのための資料・デー夕は材料のみの 科学的情報そのままでは利用され難いと思われる。このため、以下 に目整耐用年数を定める段階的プロセスを示し、屋外ばくろ試験に より得られた耐久性能データを膜構造建築物の耐久設計当初に設定 する目標耐用年数の算定に活用する方法を例示する。

[1] 建築物の耐用年数設定を支配する要求条件の選定

$\cdots \cdots$ 例：構造安全性、水密・気密等（5.参照）

[2] 耐用年数設定を支配する要求項目の選定

…要求条件から演繹された要求性能。

例 : 膜材料の強度性能 (引張・引裂強度)

[3] 選定された各要求性能項目の経時変化の様相・モードの検討

…実験、検証、実態調查結果、エキスパート判断等

趣旨に合うよう表現されたもの。例：本稿 Fig.5〜8

[4] 各要求性能項目の耐用判断基淮とデグリ一化

…要求性能が経時により耐用限界に達したと判断する場

合の基準値（レベル）とそのデグリー化の表示。

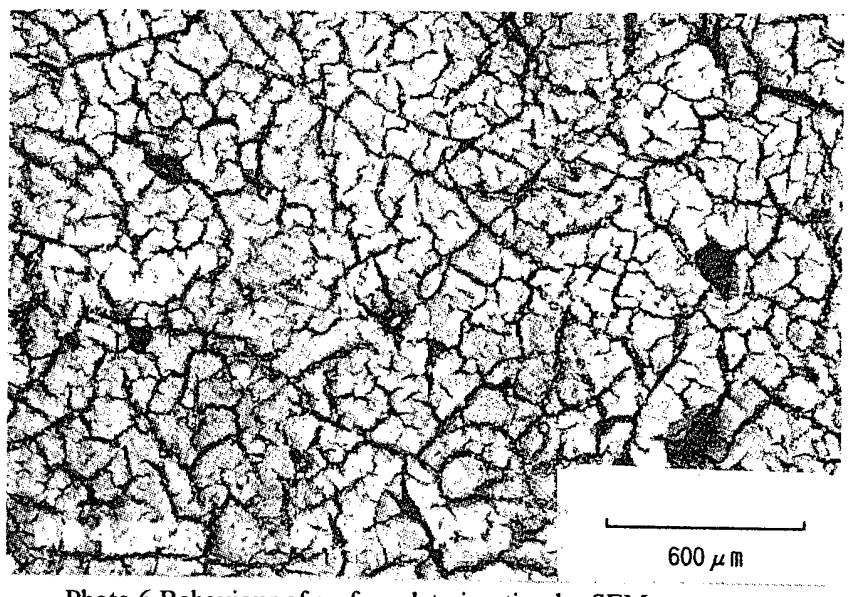

Photo.6 Behaviour of surface deterioration by SEM

after 10 years, $30^{\circ}$ facing north At material level

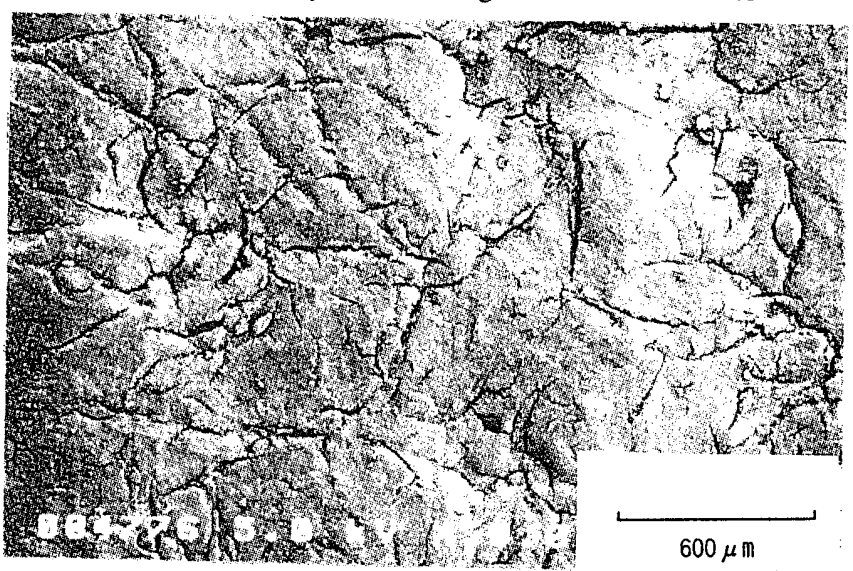

Photo. 8 Behaviour of surface deterioration by SEM

after 10 years, wall facing south At full-scale level

例 : 本稿 Table.3, Fig.9 参照

[5] 維持保全条件の想定・予測

…… [7] 以降での詳細な維持保全計画で定められる

以前の段階で想定・予測できる条件。

例 : 3 年毎に定期点検が想定できる。

[6] 維持保全条件による予想耐用年数の修正

……保全条件による予想而用年数の増・減。

例 : 3 年毎の定期点検で軽微な補修が期待可能、従って、

[3]及び[4]の段階で 9 年と判断されても、12 年間は 支障ないと判断。

[7] 目標耐用年数の設定

……最優先性能項目または複数性能項目を総合した年数とし て設定。例：膜材料の引張強度を重視し、12 年間。

膜構造建築物の構造設計要素である引張強度の変化を重視してそ の耐用年数を推定する際に必要な性能データを Fig.9 に示す。Fig.9 中のデータは Fig.5 及び Fig.6 から選定した。

実大レベルの屋外ばくろ試験データは、試験の条件が実施工され た条件に近いため、材料レベルでの試験データに比して耐用年数を 推定するためのデータとしての信頼性は高い。

Fig.9 では実大レベルの南面向き屋根部位での残存引張強度の変 化が著しく、北面向き壁部位での変化は少ない。これらの傾向は実 際の膜構造建築物の部位としての耐用年数を予想する場合に直接活 
用できる。一般に屋外ばくろ試験による建築材料の耐久性試験結果 は南面 $30^{\circ}$ にばくろされたものが多い。従って、Fig.9における南 面 $30^{\circ}$ のデータは、本研究での試験方法の相異による差の確認と、 既往の他種の膜材料との性能比較にも活用が可能である。性能指向 による組立てでは性能データを無次元化したデグリーで区分表示し、 データの効率的活用を図っている ${ }^{12)}$ 。Fig.9 の結果をもとに 5 段階 で区分表示したものを Table.3に、またこれを Fig.9 の右縦軸にも 示し、将来の耐久性能データベース化に備えることとした。

Table 3 Judging criteria for retention of tensile strength (Ts)

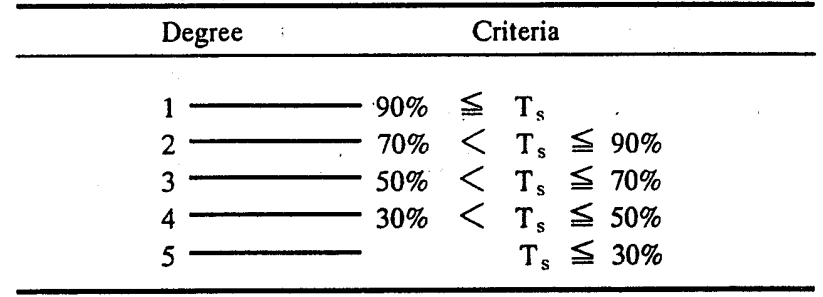

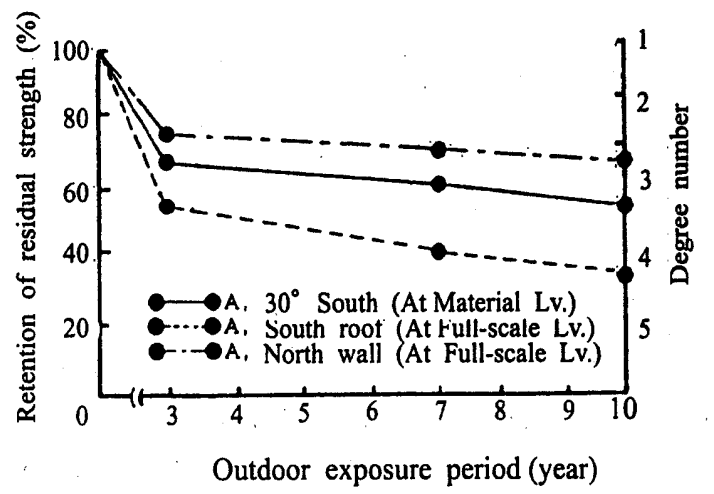

Fig.9 Degradation behaviour and criteria in tensile strength

\section{7. まとめ}

1）膜材料の品質基準に定めてある引張・引裂強度はともに求めて おく必要があり、いずれか一方で他を代用出来ない。

2) 引張・引裂強度はともにばくろ期間が 7 年間以内でも $50 \%$ 程度 低下する。但し構造安全性の低下と同列には考えられない。

3）同一品質区分にある膜材料でも、製造業者によってその性能に 差があることが予想される。この差を意識する際は、選定する 材料の技術資料等により確認する。

4) 実大レベルの試験結果からは材料レベルのそれに比して臫久設 計に有効な性能データが得られる。しかし常に実大レベルでの 試験は期待できないため、今後は既存膜構造建築物に対する実 態調查によりさらに多くの実用的性能テータの蓄樻が望まれる。

5）膜材料に対する 10 年間に亘る屋外ばくろによる性能データ、 とくに部材レベルでの実用的デー夕は希少である。今後の屋外 ばくろ試験ではより短い期間で効率的に評価が可能になり、さ らに実験室試験結果から耐用年数を推定する根拠としても活用 できる。

6) 耐久設計に際して耐用年数算定のために屋外ばくろ試験結果を 活用する方法を提案したが、そのプロセスは今後の耐用設計を 具体的に推進させようとする意図に沿ったものであり、さらな るデータの蓄樻が望まれる。
7）耐用年数を的確に予想しえない、あるいは不十分な部分を補充 するためには維持保全と組み合わせて考える手法が有効である。 この場合、劣化診断、補修方法、保全の体制を含めた維持保全 計画の重要度が高まり、建設物の竣工後はその計画が確実に履 行されることが前提である。

明 辞

本稿のうち、屋外ばくろ試験に係わるものは、建設省建築研究所 と（社）日本膜構造協会との間の共同研究に負うところが大である。 試験の実施には同協会の当時の膜構造研究委員会委員長、日本大学 岸谷孝一教授、構造分科会主查、横浜国立大学石井一夫教授の御指 導・御助言を頂いた。また多数の同協会加盟企業の方々の長期に亘 る御協力を得た。さらに、本稿の取継めに際しては工学院大学難波 蓮太郎教授の的確な御助言を頂いたことをここに深謝する。

\section{考文部}

1) The Building Regulations 1991, HMSO, U.K (英国の場合)

2) Building Code of Australia, Vol.1, 2, Australian Building Code Board, 1996 (オーストラリアの場合)

3）改正建築基準法、建設省住宅局建築指導锞監修、新日本法規出 版株発行、1999 (日本の場合)

4) 住宅の品質確保の促進等に関する法律。(財) ベターリビング、 1999 (日本の場合)

5）建物の耐久性計画に関する考え方、（社）日本建築学会、1989

6）建築物の酎久性向上技術の開発、建設省総合技術開発プロジェ クト報告書、建設省、 1985

7) ISO DIS 15686-1 Buildings - Service Life Planning - General Principle, ISO TC59/SC14, 1998

8）榆木 堯、耐久性能に関する研究(第一報)一建築材料、部材の耐 久性評価一建築研究報告 No.94、建設省建築研究所. pp.1 176,1981

9）瞙構造一その現状と展望、（社）日本膜構造協会、pp.28, 1981

10) Principal Guide for Service Life Planning of Buildings, Architectural Institutes of Japan, 1993

11）特定膜構造建築物技術基準、膜構造建築物品質管理要領，いず れも（社）日本膜構造協会、1987

12). 膜構造建築物維持保全計画指針、日本膜構造協会、1987

13). 榆木 党 他、耐久性能試験方法に関する研究（その 17）瞙構 造用膜材料の耐久性能評価について(I)，日本建築学会大会学術 講演梗概集（東北）、pp.475 476, 1987

14）豊田宏、榔木 堯 他、酎久性試験方法に関する研究（その 42） 膜構造用膜材料の耐久性能評価（II. 引張、引裂強度）日本建 築学会大会学術講演梗概集 (東北)、pp.1320-1321, 1992

15) T. Nireki et al, Degradation Behaviour of PVC-coated Fabrics for Membrane Structures, Proceedings of $6^{\text {th }}$ Int. Conf. of Durability of Building Materials \& Components, Vol.1, pp.103-111, 1993

16) JIS A1410 プラスチック建築材料の屋外暴露試験方法、1998 年版、日本規格協会 1998

17) T. Nireki, Examination of Durability Test Methods for Building Materials Based on Performance Evaluation, Int. Conf. of Durability of Building Materials \& Components, ASTM, STP 691, pp.119-130, 1980 